\title{
Increasing Public Participation through Awareness Raising Activities: A Case Study in Trao Reef Marine Reserve, Vietnam
}

\author{
Hang Thi Minh $\operatorname{Tran}^{1}$, Loke Ming Chou ${ }^{1} \&$ Hue Thu Nguyen ${ }^{2}$ \\ ${ }^{1}$ Department of Biological Sciences, National University of Singapore, Singapore \\ ${ }^{2}$ Center for Marinelife and Community Development, Viet Nam \\ Correspondence: Hang Thi Minh Tran, Department of Biological Sciences, National University of Singapore, \\ Singapore. E-mail: hang.ttm@nus.edu.sg
}

Received: October 17, 2012 Accepted: November 28, 2012 Online Published: December 3, 2012

doi:10.5539/enrr.v3n1p24

URL: http://dx.doi.org/10.5539/enrr.v3n1p24

\begin{abstract}
In the last few decades, community-based management has evolved to become an effective approach in managing natural resources and solving environmental problems around the world. In this approach, stakeholder participation is considered as a very important factor contributing to the success or failure of the management effort. To promote and enhance stakeholder participation, awareness raising activities could be conducted in various innovative forms. This is clearly illustrated in the case of Trao Reef, a locally-managed marine reserve in central Vietnam. The paper reviews the management approach applied to Trao Reef, focusing on analysis of stakeholder participation. The high level of environmental awareness of the local community contributed to the successful outcome of the project. Many communication activities and awareness raising campaigns were organized within the community to get them involved in all steps of the management process. The project enhanced the marine resources and ecosystem health, and helped to build a more sustainable livelihood and living lifestyle for the local community. Trao Reef has become a role model for effective environmental management that harmonizes the socio-economic benefits of the local community and nature conservation.
\end{abstract}

Keywords: community-based management, community awareness, environmental education, marine conservation, public participation

\section{Introduction}

Community-based management has been recognized as an effective approach to manage natural resources and solve environmental problems (Ostrom, 1992; Conroy, Mishra, \& Rai, 2002; Pretty, 2003; Matta \& Alavalapati, 2006). This approach achieved significantly positive outcomes in many places especially in developing countries (Jorge, 1997; Luttinger, 1997; Pomeroy, Pollnac, Katon, \& Predo, 1997; Alcala, 1998; Evans \& Birchenough, 2001; Maliao, 2009).

In Vietnam, community-based management has existed for many centuries in some forms of traditional management. Village community or ethnic minority groups used to manage their surrounding forest areas by themselves. This is considered to be an effective method because it is implemented using local people's knowledge and traditional community customs to sustain their livelihoods (Tran, 2007). However, community-based management in Vietnam was only officially recognized in the 1990s through the channel of development assistance from developed countries. Many community-based natural resource management projects have been implemented with the assistance from international organizations. These projects showed that community-based management is an effective and feasible approach in natural resources management in Vietnam (Nguyen \& Apel, 2000; Truong, Armitage, \& Marschke, 2010).

For successful community-based management, several key factors have to be considered. Community-based management projects conducted around the world have showed that public participation is one of the crucial factors contributing to the success of these management efforts (Pomeroy et al., 1997; Campbell \& Vainio-Mattila, 2003; Evans, Gebbels, \& Stockill, 2008; Voyer, Gladstone, \& Goodall, 2012). The importance of public participation in the process of solving environmental problems is recognized and acknowledged in many conventions and agreements around the world such as the Convention of Biodiversity Conservation and the Aarhus Convention, which highlight access to information, public participation in decision-making and access to 
justice in environmental matters. In the East Asia region where Vietnam is located, these conditions are also emphasized in regional instruments such as the Sustainable Development Strategy for the Seas of East Asia (Partnerships in Environmental Management for the Seas of East Asia, 2003) as well as the ASEAN Agreement on the Conservation of Nature and Natural Resources (Association of Southeast Asian Nations, 1985). To obtain sufficient involvement of the public, the level of environmental awareness of that community should be adequately high (Thakadu, 2005). This can be achieved through various awareness raising activities, which include campaigns, public events and communication plans to increase public awareness and participation in conservation efforts.

In the case of Trao Reef, a locally-managed marine reserve in the central region of Vietnam, many communication activities and awareness raising campaigns have been organized within the community to get them involved with all steps of the management process. This contributed to the successful outcome of the management effort. Trao Reef has become a role model of effective environmental management that harmonizes socio-economic development and nature conservation. In this paper, the management approach applied in Trao Reef is first reviewed. Second, the positive achievements of the Trao Reef management model are highlighted. Last, innovative activities conducted to increase involvement of the community are analyzed and assessed.

\section{Trao Reef Marine Reserve Community-Based Management}

\subsection{Study Area}

Trao Reef is located in Van Phong Bay of Khanh Hoa Province, a popular tourist site in central Vietnam. The adjacent community of Trao Reef is the Van Hung Commune with a total land area of 4,842 ha and a population of 10,841 people (Van Hung People Committee, 2010). More than 70\% of Van Hung's community relies on fisheries and aquaculture as their main sources of income. Trao Reef and its associated ecosystems are very important to the Van Hung community as they have contributed to the local people's livelihoods and economic development. However unsustainable practices have reduced wild commercial stocks by over $90 \%$ in a 20 year span (Bronwyn, 2009). Destructive and unsustainable fishing methods such as dynamite, cyanide and trawling have resulted in decreased fishery yield and commercial extinction of some species. This also led to coastal erosion and serious damage to coral reefs. The environmental degradation situation has become more severe from large-scale coastal aquaculture of lobster and black tiger shrimp that cause water pollution and social conflicts (Nguyen, 2010).

In an effort to mitigate environmental degradation and resource depletion, Trao Reef Marine Reserve was established in 2001 employing a co-management approach focusing on the community's role. The management is assisted by the local non-governmental organization The Centre for Marinelife Conservation and Community Development (MCD) - previously known as The International Marinelife Alliance (IMA). This is the first locally managed Marine Reserve in Vietnam that was established with high consensus and commitment from the local community. Trao Reef Marine Reserve has a total area of 89 ha with 54 ha of core zone (Figure 1). The reserve is the equivalent of an IUCN Category 2 reserve as it prohibits extractions while allowing scientific, recreational and educational activities (Nguyen, 2003).

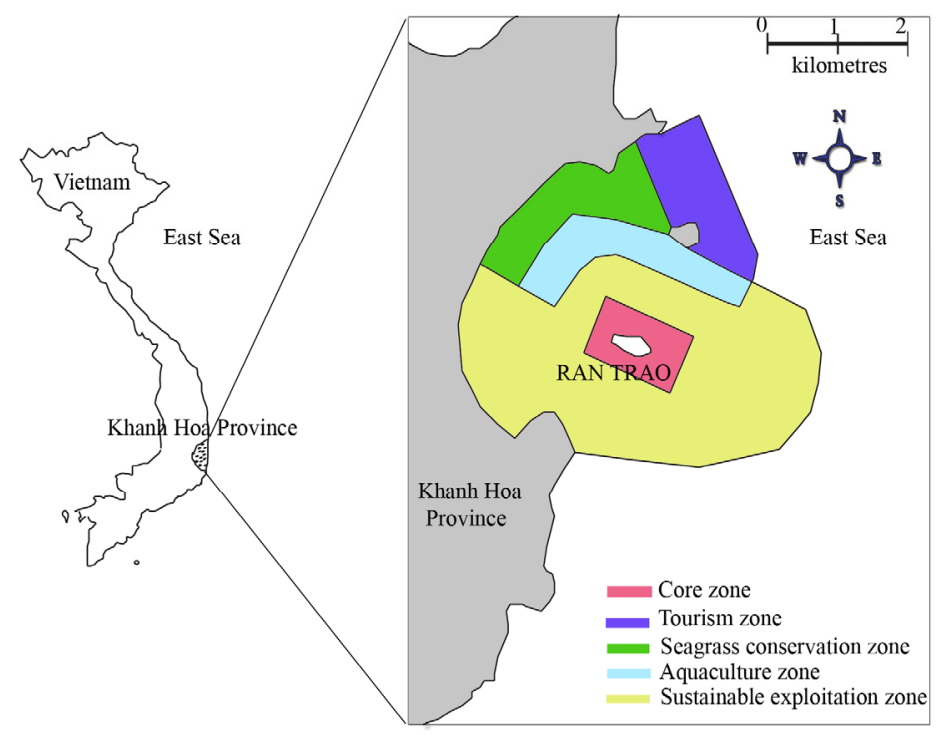

Figure 1. Map of functional zones in Trao Reef Marine Reserve 


\subsection{Trao Reef Management Model}

The establishment of Trao Reef Marine Reserve is a significant effort and a pride of the local government and local community. In order to successfully achieve the Marine Reserve's objectives, a new management mechanism was created with strong involvement of the community in all stages of management (Figure 2 and Figure 3). One of the highlights of the Trao Reef management is the formation of the Core Group comprising nine villagers and one officer from the Coast Guard force. The nine villagers were elected by the local community on a 2-year term with responsibilities to implement the Marine reserve operation. For example, they created the borders of the core zone, rehabilitated the coral reefs and guarded the core zone all day. The Core Group members are from the local community and play a very important and effective role as a bridge with local people. This strengthens commitment and involvement of the community in Trao Reef management. The community is truly involved in the execution and implementation of the management activities of the reserve.

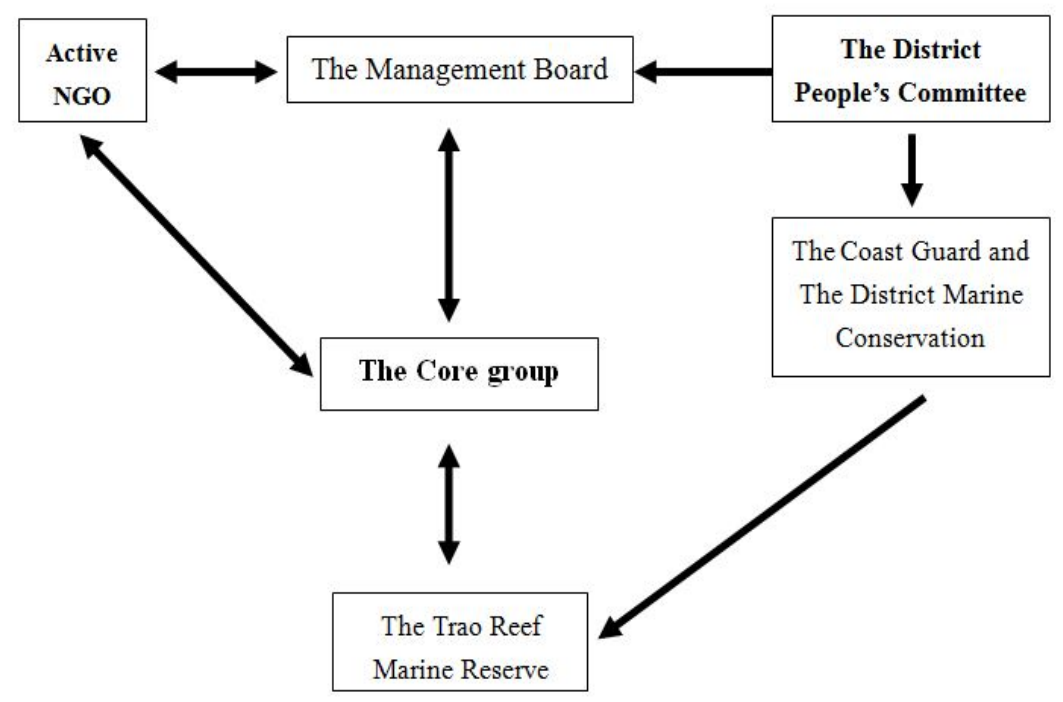

Figure 2. Management mechanism of Trao Reef Marine Reserve (Adapted from Nguyen, 2003)

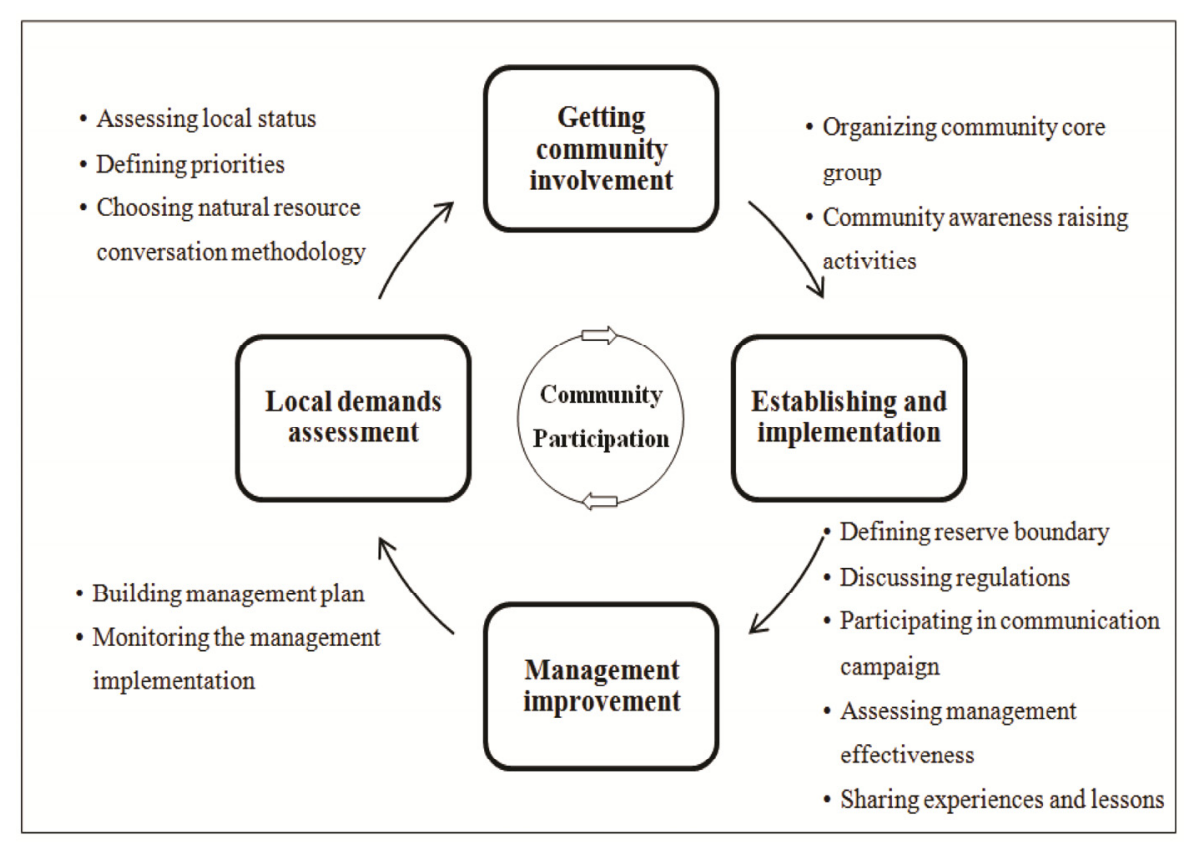

Figure 3. The involvement of the community in the management activities (Adapted from MCD, 2008) 


\section{Improvements after Trao Reef Co-management Implementation}

\subsection{Biological Resources}

Before the establishment of Trao Reef Marine Reserve, the local natural resources were over-exploited because of open access fishing. Coral reefs were heavily damaged by illegal and uncontrolled coral harvesting causing loss of the ecosystem balance. The uncontrolled expansion of aquaculture in the region also caused severe pollution to marine and coastal waters.

According to a study conducted by Nha Trang Institute of Oceanography in 2001, $50 \%$ of high commercial-value fish stocks in the area around Trao Reef were lost. In addition, fishing yield diminished from 250 tonnes per year in 1996 to 100 tonnes per year in 1999 (Van Hung People Committee, 2001).

The assessment of biological resources after the implementation of community-based management of Trao Reef showed significant improvement. The West area of Trao Reef experienced an 18.3\% increase in hard coral cover. Soft coral cover also increased steadily at Trao Reef North (Bronwyn, 2009) (Figure 4).

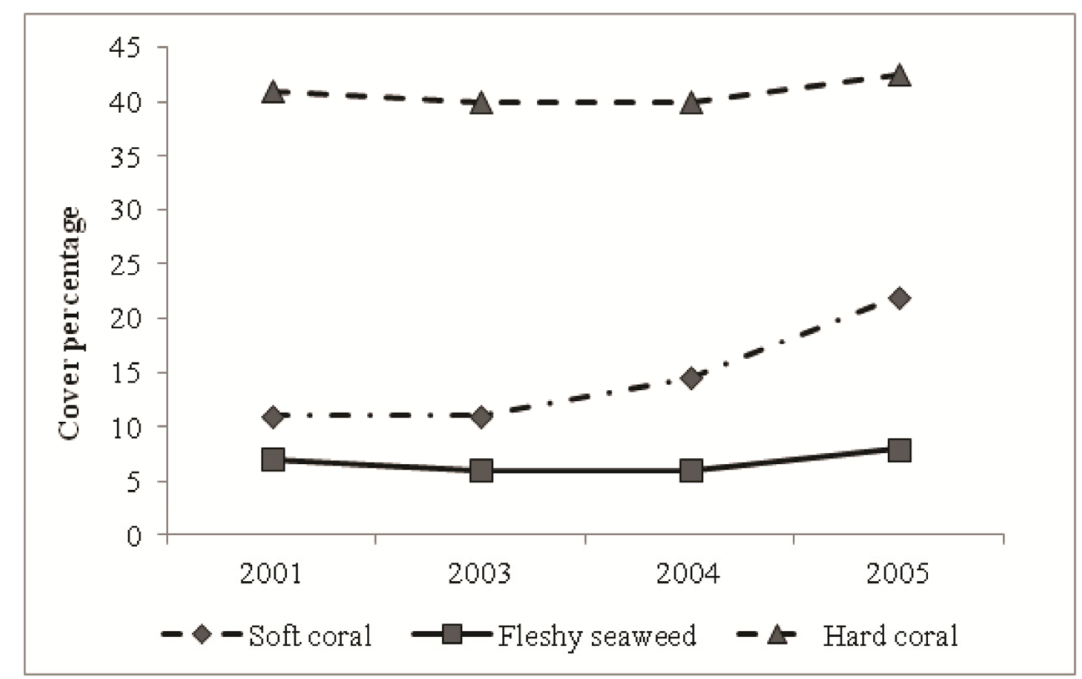

Figure 4. Percent cover of substrate types at Trao Reef from 2001-2005

Furthermore, there was a significant increase in the density of reef fishes, from 318 individuals $/ 400 \mathrm{~m}^{2}$ in 2001 to 2,500 individuals $/ 400 \mathrm{~m}^{2}$ in 2005 as showed in Figure 5 (Bronwyn, 2009).

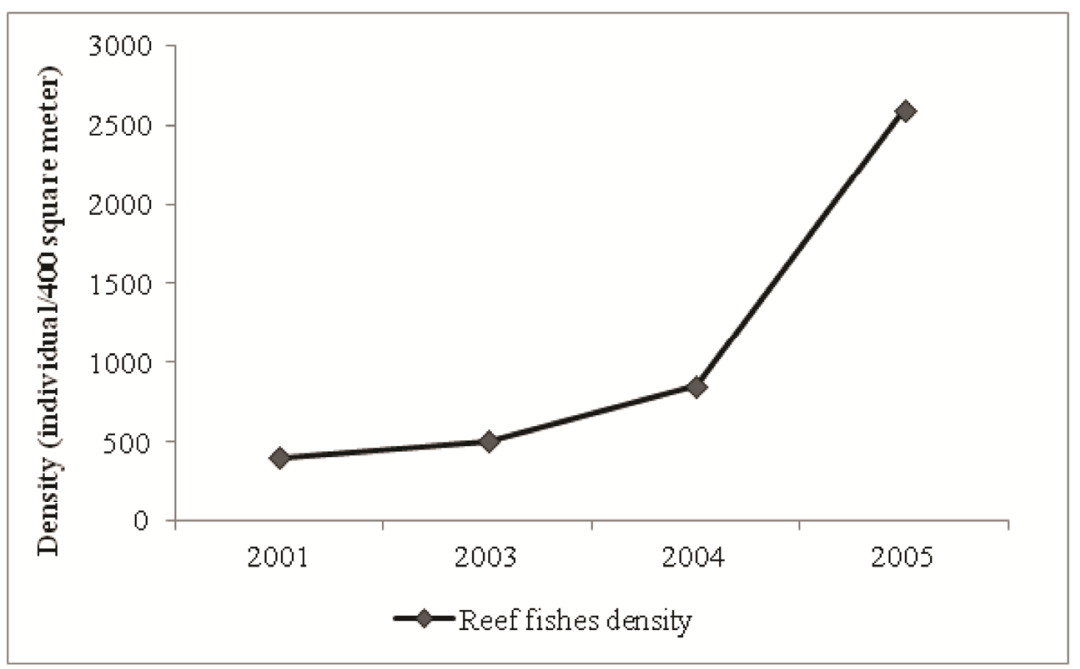

Figure 5. Total reef fish density observed across sites from 2001-2005 
Results of a survey conducted with the local community also showed that most interviewees observed a change in the resources of Trao Reef since the marine reserve was implemented (McDonald, 2005) (Figure 6).

\section{Trao Reef Marine Reserve}

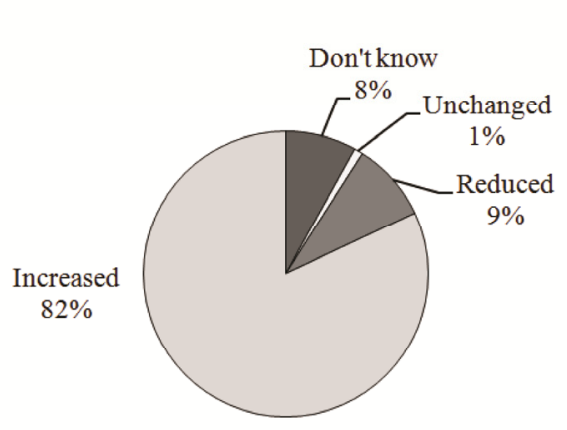

\section{Bufferzone}

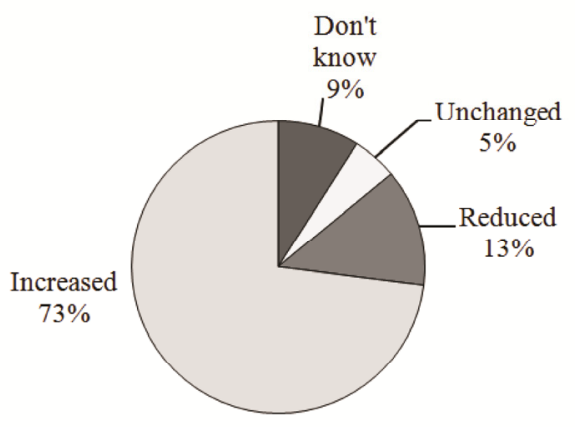

Figure 6. Respondents' opinions on change in the resources of the Trao Reef marine reserve

\subsection{Local Community Awareness and Participation}

A survey conducted by McDonald in 2005 using direct interview with a questionnaire indicated that $70.37 \%$ of local people thought that the establishment of the marine reserve came from all stakeholders' requirement. Most of the interviewees (92.59\%) agreed that establishment of Trao Reef as a reserve fulfilled the need of balancing economic development and conservation in the area. The large majority interviewed was aware of the Trao Reef management activities, and $62.96 \%$ agreed that the management was effective. This meant that they had knowledge and concern for Trao Reef and kept track of all activities. Clearly, local community awareness of the importance and the need for marine protection had increased over time.

In addition, the survey also revealed an increase in community participation in Trao Reef management implementation. All respondents (100\%) were involved in different management activities of Trao Reef (Figure 7) and all indicated their willingness to continue maintaining the marine reserve even if financial and technical support from MCD is discontinued.

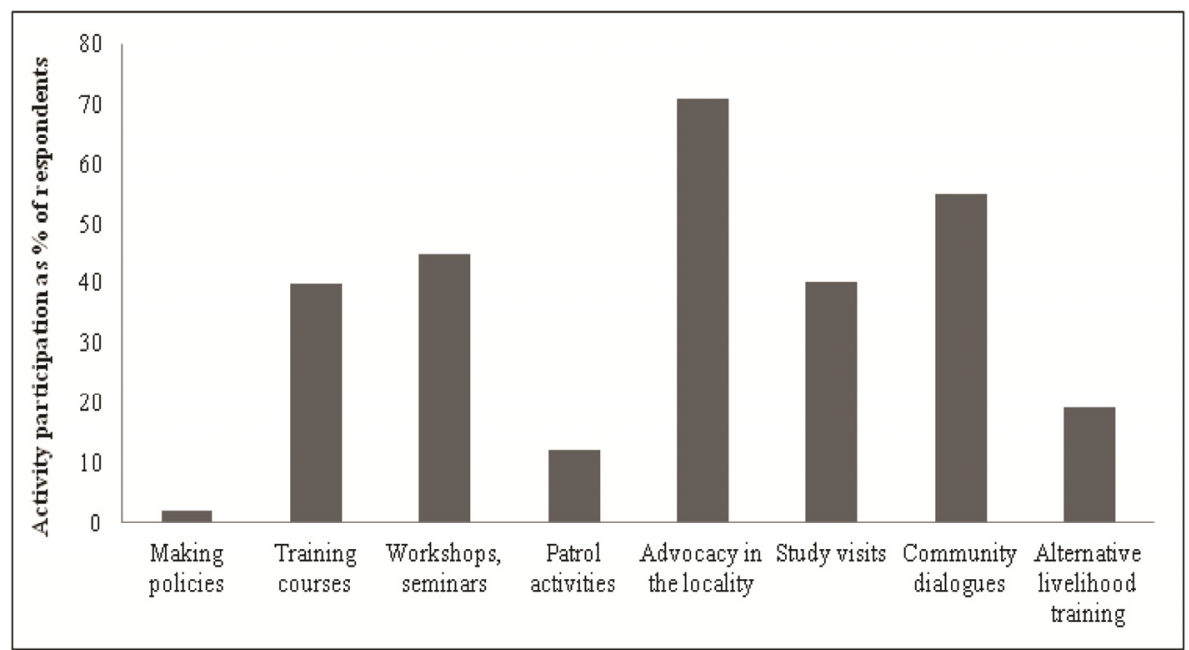

Figure 7. Respondents' participation in activities associated with the Trao Reef marine reserve

The survey results also indicated that the awareness of community about reserve regulations had increased. Most expressed that they will take necessary action should they detect any violation. 


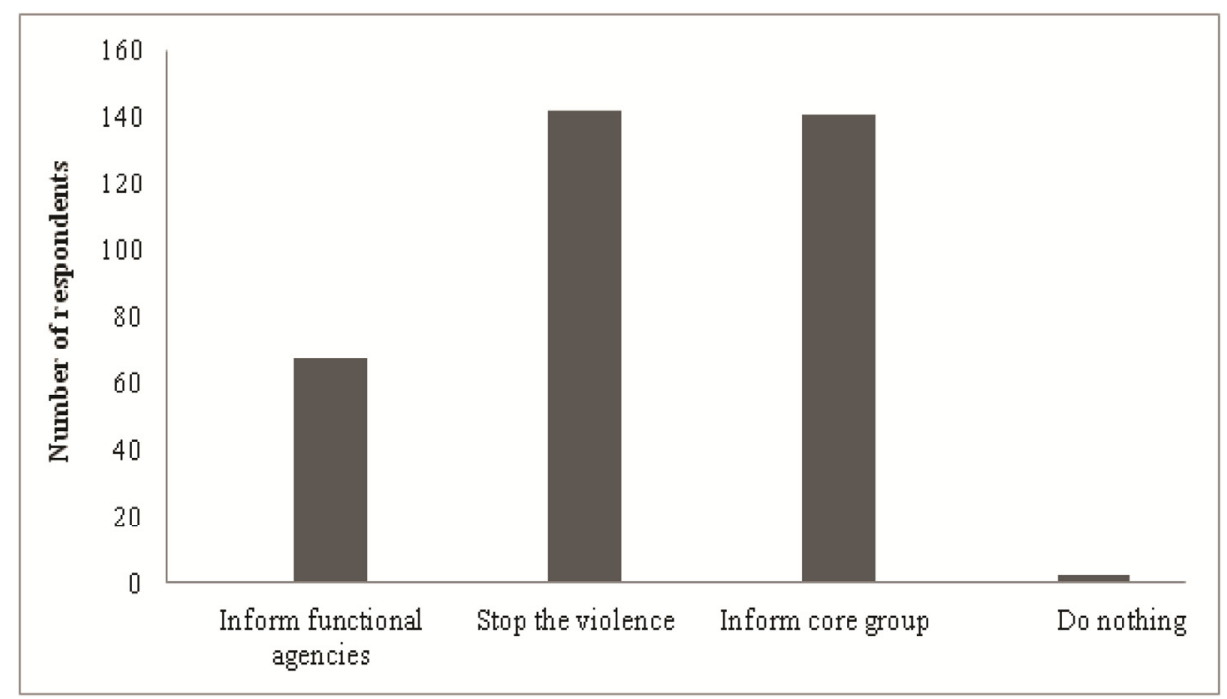

Figure 8. Action taken by respondents when violations are detected

It is clearly demonstrated that the establishment of Trao Reef Marine Reserve resulted in highly positive outcomes. One of the factors contributing to this success is the strong awareness of the community and their willingness and commitment to be involved in all Trao Reef management activities. In all stages of the Trao Reef management process, environmental education activities were strongly emphasized, which resulted in a high level of community awareness.

\section{Environmental Awareness Raising Activities}

The two most distinctive features of the Trao Reef management model are the high level of environmental awareness and the high level of local community participation. The creation of conservation awareness at the community level requires active facilitation (Chu \& Brown, 2008). In the case of Trao Reef Marine reserve, many innovative and effective methods of awareness raising were applied.

\subsection{Core Group}

The Core Group consisting of local people was formed to represent the community as well as to be involved directly with all management activities. This is a very effective way to connect with the local community as as it leverages on the existing good relationships between group members and the local community. Through the Core Group, the entire local community could be easily approached and persuaded. It appeared that the community showed greater willingness and trust when communicating and getting involved in the marine reserve activities through their representative Core Group. Knowledge on conservation and sustainable development of the Core Group was enhanced through capacity building activities that effectively enabled members to fulfil their roles of bridging the local community with the authorities, in addition to being a direct force in managing the reserve.

\subsection{Capacity Building for Officers and the Community}

To strengthen the capacity of local officers and the community, many training courses were designed to meet various demands of different sector groups. First, training was given to key local persons who are representatives of local authorities, the Core Group's members, the Women's Union and the community youth. Training included basic communication skills, marine biodiversity, resources protection and marine reserve regulations and practices. Participants then became key trainers and were capable of extending training to other groups of the community. Annually, key trainers of the community were sent to attend advanced training workshops conducted by professional environment organizations. The training created a foundation to build a knowledge chain that passes through all layers of the local community and enhance their environmental awareness.

\subsection{Regular Community Dialogues}

As part of the awareness campaign on marine conservation, many talks and dialogues have been organized regularly, at least monthly, for the local people, serving as a platform to disseminate the importance of marine conservation and the Trao Reef marine reserve. Target audience of these talks were the local youth, local women, fishermen and teachers of the local primary school. All the participants discussed and shared their thoughts and points of view on the relevant issues and the dialogues generated useful feedback and information about the 
reserve from the community.

\subsection{Public Campaigns}

Two key public campaigns that had significant impacts on community conservation awareness are the International Coastal Cleanup campaign and the Waste Collection Day campaign. Every year, International Coastal Cleanup events were conducted engaging hundreds of local villagers, youth, pupils and women. All participants have expressed their strong support for this activity. By participating, they gained more understanding of their roles and responsibility in their own marine and coastal environment. Additionally, every month, one waste collection day is also organized and promoted within the community. This regular activity reinforces the understanding of waste pollution and promotes the green and clean lifestyle.

\subsection{Communication Visual Aids}

Communication aids such as fliers and brochures are very effective in disseminating information through the community. These aids have been printed and disseminated to the community through community meetings, dialogues and family visits. A book titled "Coral Reef Education for Students and Teachers" (CREST) was also printed aimed at raising awareness on coral reef protection and conservation.

\subsection{Social Events}

Social events have been conducted to promote the pride of the local community over their valuable marine reserve. Article writing, poem composition and singing contests on marine conservation were organized. These contests further heightened awareness of the marine environment among the local community and positively changed their behaviour on resource use. Through these contests, the local community understood more about their marine environment and Trao Reef. The feeling of pride, stewardship as well as ownership was developed and increased the community's willingness and enthusiasm for conserving and maintaining the reserve.

\subsection{School Activities}

A Coral Reef Education for Students and Teachers manual was developed for local primary schools and an environmental course was added to the official curriculum to improve environmental awareness. Various external school activities such as drawing contest, writing contests, marine reserve visits and conservation games were also organized to provide children with hands-on and practical experience with their marine reserve. These activities also promoted creativity and enhanced pupils' knowledge on biodiversity of marine ecosystems.

\subsection{Community Environmental Education Center}

An environmental education center was established and fully-equipped to serve as an information hub for the community. All of the community meetings and dialogues were held in this center. It also has a collection of many environmental documents. The community can use the center as a library to improve their knowledge. The center is also a meeting point where local people can gather to talk and share their concerns about environmental problems facing local society. Gradually, the education center has become an environment and conservation "home" for the environmental friendly community.

\section{Conclusions}

The establishment of Trao Reef Marine Reserve has brought many improvements to the local community. It enhanced the marine resources and ecosystem health, and helped build a more sustainable livelihood and living lifestyle. The involvement of the local community is a major contributor to the success of the Trao Reef management model. To encourage strong public participation, many innovative and effective environmental awareness raising activities were conducted in the local area. The highlight of the Trao Reef management framework is the formation of the Core Group which played a significant role in embracing the local community with all conservation activities.

Trao Reef has become the model for a small locally managed marine area in Vietnam. The lessons and experiences of Trao Reef could be very useful and valuable to the overall context of marine conservation in Vietnam, where coastal and marine areas have been facing numerous problems. Although there are still many more factors to be considered such as legislation, policies, stake holder co-operation, the Trao Reef model has proven that the success of a conservation effort could be ensured by strong participation of the local community who are equipped with rich knowledge and high awareness about the environment and conservation.

\section{Acknowledgements}

The authors would like to thank The Center for Marinelife Conservation and Community Development in Hanoi, Vietnam for valuable help and support during the data collection period. 


\section{References}

Alcala, A. C. (1998). Community-based coastal resource management in the Philippines: a case study. Ocean and Coastal Manament, 38(2), 179-186. http://dx.doi.org/10.1016/S0964-5691(97)00072-0

Association of Southeast Asian Nations(ASEAN). (1985). ASEAN Agreement on the Conservation of Nature and Natural Resources. Retrieved from http://cil.nus.edu.sg/1985/1985-agreement-on-the-conservation-of-nature-and-natural-resources-signed-on-9 -july-1985-in-kuala-lumpur-malaysia-by-the-foreign-ministers/

Bronwyn, J. C. (2009). Assessment Report for Trao Reef. Working paper. Center for Marinelife conservation and community development, Vietnam.

Campbell, L. M. \& Vainio-Mattila, A. (2003). Participatory Development and Community-Based Conservation: Opportunities Missed for Lessons Learned? Human Ecology, 31(3), 417-437. http://dx.doi.org/10.1023/A:1025071822388

Chu, M. T., \& Brown, P. C. (2008). Community participation in marine conservation in Vietnam: a case study from $\mathrm{Cu}$ Lao Cham MPA. Pre-conference workshop proceedings of Global Forum on Ocean, Coasts and Islands, Quang Ninh, Vietnam.

Conroy, C., Mishra, A., \& Rai, A. (2002). Learning from self-initiated community forest management in Orissa, India. Forest Policy and Economics, 4(3), 227-237. http://dx.doi.org/10.1016/S1389-9341(01)00068-5

Evans, S. M., \& Birchenough, A. C. (2001) Community-based management of the environment: lessons from the past and options for the future. Aquatic Conservation: Marine and Freshwater Ecosystems, 11(2), 137-147. http://dx.doi.org/10.1002/aqc.434

Evans, S. M., Gebbels, S., \& Stockill, J. M. (2008). 'Our shared responsibility': participation in ecological projects as a means of empowering communities to contribute to coastal management processes, Marine Pollution Bulletin, 57(1-5), 3-7. http://dx.doi.org/10.1016/j.marpolbul.2008.04.014

Jorge, M. A. (1997). Developing capacity for coastal management in the absence of the government: a case study in the Dominican Republic. Ocean and Coastal Management, 36(1-3), 47-72. http://dx.doi.org/10.1016/S0964-5691(97)00017-3

Luttinger, N. (1997). Community-based coral reef conservation in the Bay Islands of Honduras. Ocean and Coastal Management, 36(1-3), 11-22. http://dx.doi.org/10.1016/S0964-5691(97)00014-8

Maliao, R. J., Pomeroy, R. S., \& Turingan, R. G. (2009). Performance of community-based coastal resource management programs in the Philippines: A meta-analysis. Marine Policy, 33(5), 818-825. http://dx.doi.org/10.1016/j.marpol.2009.03.003

Matta, J. R., \& Alavalapati, J. R. R. (2006). Perceptions of collective action and its success in community based natural resource management: An empirical analysis. Forest Policy Economics, 9(3), 274-284. http://dx.doi.org/10.1016/j.forpol.2005.06.014

MCD (Centre for Marinelife Conservation and Community Develoment). (2008). The Development and implementation of a Locally Managed Marine Protected Area in Vietnam.

McDonald, A. (2005). Report on the Socio-Economic and Biological Evaluation of Trao Reef Locally Managed Marine Reserve. Working paper. Center for Marinelife conservation and community development, Vietnam.

Nguyen, L. A. (2003). Co-Management For A Marine Reserve Area: A Case Study Of The Van Hung Commune, Khanh Hoa Province, Vietnam, MSc Thesis, School of Environment, Resources and Development, Asian Institute of Technology, Thailand.

Nguyen, T. H. H. (2010). Co-management in trao reef marine reserve, Vietnam: a transaction costs approach, MSc. Thesis, The Norwegian College of Fishery Science, University of Tromso, Norway and Nha Trang University, Vietnam

Nguyen, T. V., \& Apel, U. (2000). Community Forest Management strategy of Social Forestry Development Project, Da River. Proceedings of the Workshop on Experience and Potentiality of Community Forest Management in Vietnam., Hanoi, Vietnam.

Ostrom, E. (1992). The rudiments of a theory of the origins, survival, and performance of common-property institutions. In: Bromely, D. W. (Ed.). Making the Commons Work: Theory, Practice and Policy. ICS press, San Francisco. 
Partnerships in Environmental Management for the Seas of East Asia (PEMSEA) (2003). Sustainable Development Strategy for the seas of East Asia. Retrieved from $\mathrm{http}: / /$ pemsea.org/knowledge-center/the-sds-sea/the-sds-sea

Pomeroy, R. S., Pollnac, R. B., Katon, B. M., \& Predo, C. D. (1997). Evaluating factors contributing to the success of community-based coastal resource management: the Central Visayas Regional Project-1, $\begin{array}{llll}\text { Philippines. Ocean and Coastal Management, 36(1-3), } & \text { 97-120. }\end{array}$ http://dx.doi.org/10.1016/S0964-5691(97)00016-1

Pretty, J. (2003). Social capital and the collective management of resources. Science, 302, 1912-1914. http://dx.doi.org/10.1126/science.1090847

Thakadu, O. T. (2005). Success factors in community based natural resources management in northern Botswana:

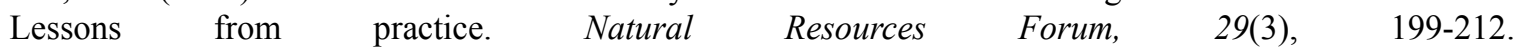
http://dx.doi.org/10.1111/j.1477-8947.2005.00130.x

Tran, D. V. (2007). Land Policies and Community-based Natural Resources Management in Vietnam's Uplands. In Proceedings of Regional Conference on Environmental Planning and Planning and management Issues in Southeast Asian Countries. Hanoi Agricultural Publishing House, Hanoi.

Truong, V. T., Armitage, D., \& Marschke, M. (2010). Livelihoods and co-management in the Tam Giang lagoon, $\begin{array}{llll}\text { Vietnam. Ocean } \text { and } & \text { Coastal 327-335. }\end{array}$ http://dx.doi.org/10.1016/j.ocecoaman.2010.04.001

Van Hung People Committee. (2001). Annual Report.

Van Hung People Committee. (2010). Annual Report.

Voyer, M., Gladstone, W., \& Goodall, H. (2012). Methods of social assessment in Marine Protected Area planning: Is public participation enough? Marine Policy, 36(2), 432-439. http://dx.doi.org/10.1016/j.marpol.2011.08.002 